7 Ste-Marie, M T, Lee, E M, and Brown, W R, Paediatric Research, 1974, $8,815$.

${ }^{8}$ Haneberg, B, Scandinavian fournal of Immunology, 1974, 3, 191.

${ }^{9}$ Barlow, B, et al, fournal of Pediatric Surgery, 1974, 9, 587.

10 György, P, Pediatrics, 1953, 11, 98.

11 Sabin, A B, and Fieldsteel, A H, Pediatrics, 1962, 29, 105.

12 Falkler, W A, Diwan, A R, and Halstead, S B, Archives of Virology, 1975, 47, 3.

13 Taylor, B, et al, Lancet, 1973, 2, 111.

14 Walker, W A, Pediatric Clinics of North America, 1975, 22, 731.

15 Gunther, M, Lancet, 1975, 1, 441.

16 Freier, S, Clinical allergy, 1973, 3 (Suppl.), 597

17 Boat, T F, et al, fournal of Pediatrics, 1975, 87, 23.

18 Henschel, M J, and Coates, M E, Proceedings of the Nutrition Society, 1974 33, $112 \mathrm{~A}$.

19 Department of Health and Social Security, Present-day Practice in Infant Feeding. London, HMSO, 1974.

20 Valman, H B, Update, 1975, 611.

${ }^{21}$ Beer, A E, Billingham, R E, and Head, J, Fournal of Investigative Dermatology, 1974, 63, 65.

22 Beer, A E, and Billingham, R E, Annals of Internal Medicine, 1975, 83, 865.

${ }^{23}$ Deforest, A, et al, Fournal of Pediatrics, 1973, 83, 93.

${ }^{24}$ Linnemann, C C, and Goldberg, S, Lancet, 1974, 2, 155.

\section{Alcohol and the brain}

It is widely known that alcohol can cause brain damage. ${ }^{1}$ This is roughly proportional to the intensity and the duration of the abuse, but other factors (particularly dietary) play an important part. What is not generally realised, however, is that alcoholic brain damage is in no way uncommon; and Lemere ${ }^{2}$ has emphasised that "for each alcoholic with demonstrable pathology, there must be thousands in intermediate stages of danger."

The classic symptoms of irreversible alcoholic brain damage are related to disturbances of memory. In severe cases the Korsakoff phenomenon is present, characterised by retention of memory for remote events but with serious impairment of memory for the recent past, amounting in certain cases to instant forgetting. Other intellectual abilities are, however, also impaired. A study by Clarke and Haughton ${ }^{3}$ and another by Clarke alone, ${ }^{4}$ both conducted in Ireland, showed that both visual-motor and visual-spatial functions were affected, and, furthermore, that the impairment could still be shown when the patients tested (many of them young men) had not been drinking for ten weeks. Paradoxically, perhaps, verbal skills remained relatively intact-a phenomenon that may serve to camouflage the extent or even the existence of brain damage.

The serious implications arising from these findings are highlighted by the authors. Some of the men they tested were engaged in highly skilled occupations such as engineering and architecture demanding refined visual-spatial reasoning. When, if ever, they would be fit to resume work was far from certain. Of greater importance, because it affects the safety of the public, is the fitness of such brain-damaged people to drive motor vehicles-a complicated series of manoeuvres requiring not only visual-spatial but also visual-motor skills of a high order.

Clare and Cooney ${ }^{5}$ have drawn attention to the association between alcoholism and road accidents, emphasising the lack of attention paid to the contribution by the alcoholic to the steadily increasing accident rate on the roads. Alcoholics in Ireland are strictly comparable with those in other parts of the world: they have many more road accidents and prosecutions than control groups of non-alcoholic drivers. Clare and Cooney also confirm that an accident or prosecution in which alcohol was a factor tends to occur early in an alcoholic's history; they suggest that such a history should be looked for as routinely as other classical signs and symptoms of alcoholism.
Studies such as these should have a wider applicability. More determined efforts should surely be made to identify alcoholic drivers as opposed to the driver with a "one-off" illegal level of alcohol in his blood. Once identified, treatment should, perhaps, be compulsory in order to prevent the irreversible brain damage which would render the culprit even more of a menace than he already is; and until such time as treatment and rehabilitation have been completed the licence to drive should be withheld. Such a procedure might be considered in certain quarters as an infringement of the liberty of the individual, but to the vast majority of ordinary citizens it will be justified by the unacceptable carnage on the roads.

1 Brewer, C, and Perrett, L, British fournal of Addiction, 1971, 66, 170.

2 Lemere, F, American fournal of Psychiatry, 1956/57, 113, 361.

3 Clarke, J, and Haughton, H, British fournal of Psychiatry, 1975, 126, 178

4 Clarke, J, Irish Medical fournal, 1976, 69, 29.

5 Clare, A W, and Cooney, J G, fournal of the Irish Medical Association, 1973, 66, 281.

\section{Quality of life}

Recently the British Geriatrics Society, the British Society for Research on Ageing, and the British Society for Social and Behavioural Gerontology held a joint meeting at Keele University, which was particularly appropriate in Age Action year. This was an exciting innovation in communication among all those specialising in the care of the elderly and was particularly valuable to geriatricians in enabling them to discuss ideas and progress in allied subjects of study.

The quality of life in long-stay accommodation was a prominent theme. The traditional concept of patients in longstay hospitals was questioned, since there could well be those whose full capacity to help themselves or the community was not being developed, in spite of enthusiastic nursing, physiotherapy, and occupational therapy. Attempts had been made in two long-stay geriatric hospitals to bring patients into the organisation and improvement of their care. In one case a committee had been set up from among the more intellectually able patients, but the project was unsuccessful since "institutionalisation" appeared to have stultified any desire or initiative for change among the patients. The results of a second attempt, which had co-opted a patient on to the hospital staff committee, seemed more promising and new ideas for improving patient care had followed. Geriatricians at the meeting argued, however, that, while the idea of patient participation might be excellent and helpful in establishments such as the Cheshire Homes, their own patients were far too confused to make any constructive contributions to their care; any who were alert enough to contribute had usually been discharged. Perhaps the idea of patient participation might be developed more appropriately by community health councils.

The quality of life for the elderly in old people's homes was also of particular concern. Individuals needing nursing care and admission to hospital were being admitted to old people's homes because of a shortage of geriatric beds, which encouraged homes to be run on hospital lines-with a matron in charge, fixed meal and bathing times, daily drug rounds, and written rules. Residents tended to be "streamed" to separate the more able from the noisy, the confused, and the incontinent. Taking an independent role or contributing to the running of the home by residents was discouraged. Institutionalisation was further 